\title{
B cell subsets phenotype in autoimmunity with immunodeficiency: analysis of a cohort of patients with APECED syndrome
}

\author{
A Magnani ${ }^{1 *}$, A Meloni $^{2}$, M Gattorno ${ }^{1}$, A Martini $^{1}$, E Traggiai $^{1}$ \\ From 18th Pediatric Rheumatology European Society (PReS) Congress \\ Bruges, Belgium. 14-18 September 2011
}

\section{Background}

Autoimmune polyendocrinopathy candidiasis ectodermal dystrophy (APECED) is a rare autosomal recessive syndrome due to mutations in AIRE, characterized by autoimmune endocrinopathies and mucocutaneous candidiasis. It is accompanied by serum auto-antibodies whose generation has been mainly related to autoreactive $\mathrm{T}$ cells escape from tolerance mechanisms. Recent data suggest a $\mathrm{T}$ cell independent mechanism implicated in altered peripheral $\mathrm{B}$ cell selection and its possible contribution to the pathogenesis of autoimmune disease. Despite these observations, B cell subsets phenotype in these patients is still poorly characterized.

\section{Aim}

To perform a detailed analysis of $B$ and $T$ cell subsets in a cohort of APECED patients in order to better understand whether an intrinsic alteration in B cell compartment is present. We also evaluated B lymphocytes related cytokines (BAFF, IL-21) in patients' sera compared to age matched control.

\section{Methods}

Flow cytometric analysis of B cell subsets was performed in 12 patients with APECED coming from Sardinia, Italy, compared to age-matched healthy donors. The following B cell subsets were analysed: transitional, naïve, IgM and switched memory and plasmacells; T cell subsets: Treg, CD4 and CD8 T cell subsets (naïve, central memory, effector memory) ELISA assay was performed for cytokines determination in sera.

\section{Results}

Analysis show an altered distribution of the immature peripheral B cells compartment in APECED patients and an increased level of BAFF in patients' sera. The $\mathrm{T}$ cell compartment is skewed towards effector memory $\mathrm{T}$ cells.

\section{Conclusions}

Increasing the knowledge on B cells in APECED patients improves the comprehension of autoimmunity pathogenesis in immunodeficiency and may allow the exploration of the possible clinical efficacy of B cell targeted therapy.

\section{Author details}

${ }^{1}$ Laboratory of Immunology of Rheumatic Diseases,U.O. Pediatria II, G. Gaslini Institute and Department of Pediatrics, University of Genoa, Italy. ${ }^{2}$ Pediatric Clinic II, Ospedale Microcitemico and Department of Biomedical and Biotechnological Science, University of Cagliari, Italy.

Published: 14 September 2011

doi:10.1186/1546-0096-9-S1-P285

Cite this article as: Magnani et al:: B cell subsets phenotype in autoimmunity with immunodeficiency: analysis of a cohort of patients with APECED syndrome. Pediatric Rheumatology 2011 9(Suppl 1):P285.

\footnotetext{
* Correspondence: AlessandraMagnani@ospedale-gaslini.ge.it

'Laboratory of Immunology of Rheumatic Diseases,U.O. Pediatria II, G. Gaslini

Institute and Department of Pediatrics, University of Genoa, Italy

Full list of author information is available at the end of the article
}

(c) 2011 Magnani et al; licensee BioMed Central Ltd. This is an open access article distributed under the terms of the Creative Commons Attribution License (http://creativecommons.org/licenses/by/2.0), which permits unrestricted use, distribution, and reproduction in any medium, provided the original work is properly cited. 